\title{
Quality Engineering
}

\section{Duality Ensineaing}

\section{A review of critical success factors for the successful implementation of lean six sigma and six sigma in manufacturing small and medium- sized enterprises}

\section{Roland Stankalla, Oksana Koval \& Felicita Chromjakova}

To cite this article: Roland Stankalla, Oksana Koval \& Felicita Chromjakova (2018): A review of critical success factors for the successful implementation of lean six sigma and six sigma in manufacturing small and medium-sized enterprises, Quality Engineering, DOI: 10.1080/08982112.2018.1448933

To link to this article: https://doi.org/10.1080/08982112.2018.1448933

Accepted author version posted online: 21 Mar 2018.

Submit your article to this journal

Џ Article views: 6

Q View related articles $₫$

View Crossmark data $\asymp$ 
PUBLISHER: TAYLOR \& FRANCIS

JOURNAL: QUALITY ENGINEERING

DOI: HTTPS://DOI.ORG/10.1080/08982112.2018.1448933

A REVIEW OF CRITICAL SUCCESS FACTORS FQR THE SUCCESSFUL

IMPLEMENTATION OF LEAN SIX SIGMA AND six̀ SIGMA IN MANUFACTURING

SMALL AND MEDIUM-SIZED ENITERPRISES

Roland STANKALLA, Oksana KCVAL, Felicita CHROMJAKOVA 
Abstract

Organizations embarking on implementation of Lean Six Sigma and Six Sigma improvement initiatives need to overcome substantial barriers to ensure effectiveness of the implemented approaches. In many cases, implementation of improvement initiatives involves significant investment in establishment of supporting infrastructure and training for the improvement initiatives. While Lean Six Sigma and Six Sigma were initially applied within large corporations, the interest of small and medium-sized enterprises in improvement initiatives is increasing. Implementation of Lean Six Sigma and Six Sigma faces unique barriers in smal! and medium-sized enterprises associated with the size and availability of the resources. Thus, the a im of this article is to examine the critical success factors that condition successfulress of Lean Six Sigma and Six Sigma implementation in manufacturing small and medium-sized/enterprises. Based on seven articles from six countries (UK, India, Italy, Kenya, Netherland, Málaysial, the importance of the different critical success factors are examined and compared. Further, the proposed study examines differences in the importance of the critical success factors between small and medium-sized enterprises and large corporations. For the conduct of this anaivsis, six additional papers from Europe, India and Brazil concerning critical success faciors for the implementation of Six Sigma and Lean Sigma in larger manufacturing enterprises were taken into account. Moreover, five priority groups of critical success factors are develorea for botn organization sizes based on a percentile distribution. The analysis of the identified groups demonstrates similarities in the critical success factors for both types of organizations. In conclusion, it can be stated that "top management commitment" and "linking Six Sigina to business strategy" are the top priority critical success factors, for both small and mediumsizzed enterprises and large organizations. Additionally, for small and medium-sized enterprises, it is necessary to develop a good communication plan and link Six Sigma to customers. 


\section{INTRODUCTION}

About a decade ago, small and medium-sized enterprises (SMEs) were considered as the lifeblood of a modern economy (Antony et al. 2005). The growing importance of supply chain management issues in a global market environment make large firms heavily dependent on SMEs when it comes to the provision of high-quality products or services at low cost. To ensure cost effectiveness, SMiEs consider the introduction of business strategies like Six Sigma (SS) or Lean Six Sigma (LSST) Antony et al. 2005). Until now, LSS and SS have been implemented extensively and succescf.ally in the larger industrial units. The current literature demonstrates that during the last decade inore and more research papers about the implementation of these quality strategies were also carried out with focus on smaller organizations (e.g. Kumar et al. 2006; Jie $\in$ t al. 2014, fetc.). However, many key questions remain unanswered and the need for more investigation into the application of these initiatives in SMEs is strongly recommended (Antony et al.200\%; Kumar and Antony, 2008, 2009).

Various authors argue that LSS or SS can be irnplemented successfully in any organization, irrespective of the size of the company Furthermore, there is no evidence of implausibility of LSS or SS implementation in SMEs (Kurnar and Aitony, 2009). However, the original SS deployment is not applicable for SMEs due to numerois differences between these two organization sizes (Rowlands, 2004). Moreover Deshmukin and Chavan (2012) advised that some changes are required in the SS approach in S.MEs, as it cannot be used like in large organizations. For this reason, many researchers have weer, highilighting a need for a specific standard framework and roadmap with clear guidance regarding the implementation of LSS and SS in SMEs in the last years (e.g. Husband and Mandal, 1999; Kumar et al. 2006; Deshmukh and Chavan, 2012; Pepper and Spedding, 2009). A common approach used in developing continuous improvement strategies is to identify factors or elements that are believed to be critical for the successful implementation of such concepts (Kifayah and Douglas, 2008). Therefore, the objective of this paper is to review critical success factors for the implementation of LSS and SS in manufacturing SMEs. For this purpose, this study compares critical 
success factors (CSFs) for the implementation of LSS and SS in manufacturing SMEs, established in previous research. Furthermore, the importance of the individual CSFs for SMEs will be benchmarked to those of larger enterprises to identify differences in the priority of the CSFs between these two organisation sizes.

To achieve the proposed objective, this research paper is organized into six chapters. In chaoter 2, theoretical fundamentals will be discussed, followed by a detailed overview of the research. questions and the methodology (chapter 3). Chapter 4 outlines the current state of research and chapter 5 discusses the results and findings. Finally, in chapter 6 , the conclusion and future research proposals are presented.

\section{THEORETICAL FUNDAMENTALS}

\subsection{Lean Six Sigma}

SS is a disciplined and data-driven business improvernent methodology that was developed to enhance the quality of processes with the objective of establishing an almost zero-defect quality strategy, thereby increasing cusiomer sacisfaction as well as improving financial results. Bill Smith from Motorola/USA deveijped SS in 1987. Based on the ideas of statistical process control, Motorola defined "Six Sign:a" as 3,4 defects per million opportunities in a given production process. Sigma $(\sigma)$ is used io represent the variation (standard deviation) of a process mean. "Six" means that the distance between the mean and the critical tolerance limits shall be 6 standard deviations constantly (A,rnheiter and Maleyeff, 2005; Pyzdek, 2003). Furthermore, SS is also being widely recognized as an effective leadership development tool. After 1995, SS was enhanced by General Electric as a business strategy used to improve business profitability. It was initially applied in the manufacturing sector but has now spanned over service, financial, healthcare and public sectors (Coronado and Antony, 2002). In 2003, LSS was established as part of the evolution of SS. It is the combination of Lean Management and SS which are the most popular business strategies for 
enabling continuous improvement and improved bottom-line results (Albliwi et al. 2015). This combination is achieved by merging tools and principles to overcome the weaknesses while bringing out the advantages of both programs. Lean focuses on removing all types of waste from the process (the efficiency issue) while SS concentrates on controlling the process statistically and removing variation from the process (the effectiveness issue). The phrase "Lean Six Sigma" is therefore used to describe the integration of both these approaches into a comprehensive management sysiem (Arnheiter and Maleyeff, 2005).

\subsection{Small and medium-sized enterprises}

From the 1990s onward, with the globalization of the world market, a conitiviuous trend toward downsizing large firms and outsourcing business to smaller firms emerged (Antony et al. 2005; Kumar and Antony, 2008). SMEs make up for $99.8 \%$ of the total number of enterprises, employ $66.5 \%$ of the total workforce and contribute $575 \%$ of the teial value added to the EU. Moreover, more than $50 \%$ of the employees from man ufacturing crompanies in the European Union are working in SME manufacturing companies (Gagliardi $\epsilon^{t}$ al. 2013). For these reasons, SMEs have been increasingly studied by scholars. Tahle 1 shows a detailed definition of SMEs, which was proposed by the European Commission 20051 , adspted by the European Union Member States and entered into force in 2005. 


\begin{tabular}{|c|c|c|c|c|c|}
\hline Enterprise size & Employees & & Annual turnover & & Annual balance sheet total \\
\hline Large & $>250$ & & $>€ 50$ million & & $>€ 43$ million \\
\hline Medium-sized & $<250$ & AND & $<€ 50$ million & OR & $<€ 43$ million \\
\hline Small & $<50$ & & $<€ 10$ million & & $<€ 10$ million \\
\hline Micro & $<10$ & & $<€ 2$ million & & $<€ 2 r$ \\
\hline
\end{tabular}

\subsection{Critical Success Factors}

In order to understand how LSS can be successfully implemented CSFS sf LSS need to be identified. The idea of identifying CSFs as a basis for determining the iniornation needs of managers was originally popularized by Rockart (1978). CSFs are those essential factors which are critical for the success of any program, company or organization (Corcnado and Antony, 2002; Rockart, 1978). For this reason, those few essential aspects must be given special and continual attention to make sure that they will be performed weil in orde to ensure enterprise success. According to Griffin (1995) CSFs are a limited number of areas in which satisfactory results will ensure a successful competitive performance. However, if results associated with these factors are not achieved, the program will fail catastrophica!ly with serious negative consequences for the whole organization and its future success (Rockart. 1978). Moreover, if any of the critical success factors are missing during the develcpment and implementation stages of a LSS program, it could constitute the difference between a successful implementation and a waste of resources, effort, time and money (Antony and Banuelas, 2002). Jenster (1987) as well as Griffin (1995) concluded in their studies that companies using CSFs received a higher return on equity compared to companies that did not employ the CSF methodology. CSFs are interdependent, however, each one has its own requirements and potential short- and long-term implications (Antony and Coronado, 2002). 


\section{RESEARCH FRAMEWORK}

Basically, the study is prepared to answer the following research questions:

RQ1: How often did the individual CSFs occur in the different SME studies?

RQ2: What importance factors and ranks are assigned to the individual CSFs in the SME stlidies and how do these values differ from each other in the various SME studies?

RQ3: What are the differences of the importance factors, ranks and occurrence freauencies of the individual CSFs between SMEs and larger enterprises?

RQ4: What CSFs shall be prioritized in SMEs and large entervitises anc' what are the differences in the prioritization of CSFs between these two organization sizes?

To answer these research questions a systematic literature review was conducted. According to Okoli and Schabram (2010), a systematic literature revie'w is "a systematic, explicit, comprehensive and reproducible method for identifying, eva!uating, and synthesizing the existing body of completed and recorded work prodiced ky researchers, scholars, and practitioners". For this reason, the research starts with an analysis of tiie empirical studies that have been conducted with regard to CSFs for the LSS or SS in:piementation regardless of the size of the organisation in order to get a comprehensive jverview about the research field. Thereafter, the focus will be specified on the investigation of SMIES. For this review, only journal papers from academic databases have been taken into consideration since academics mainly use articles of the highest level of research findings to obtain information and to disseminate their own research findings. Therefore, information from editorials, news reports, textbooks and conference papers was not included in this study. Various high-quality online journal databases like Emerald, Science Direct (Elsevier), ProQuest, Interscience, Taylor \& Francis were selected and searched to generate a comprehensive bibliography. These databases provide online access to complete research texts and abstracts of a lot of high-quality 
articles. The following search strings were used to identify the research articles of interest: [(Lean Six Sigma) or (Six Sigma) AND (Critical Success Factors) AND (SME)]. These criteria ensure a comprehensive set of high-quality, peer-reviewed articles. The selected articles were carefully reviewed and were selected for further research when they included a survey. In most cases the survey measurement used in these articles is a five-point Likert scale, representing the respondents perceived importance of each CSF (1 - "not very important"; 2 - "not important"; 3 - "important"; 4 - "very important"; 5 - crucial). The authors of these papers designed structured questioninaires and sent them to companies. The applied CSFs in these surveys were derived kased on their own literature reviews about LSS, SS and TQM. The profile of the respondents seiected tor the surveys were in most cases LSS experts such as Master Black Belts, Black Belt, Green Belts, CEOs, Directors, General Managers, Middle Managers, Quality Managers and Production professionals. Finding out the perception of CSFs from those who have a great undersiariding and practical experience in the actual industrial environment is crucial (Habidin and Yusof, 2013). In addition to answer RQ4, the CSFs for SMEs and larger enterprises are lassified into five groups according a percentile distribution, ranging from lower to ton priority.

\section{CURRENT STATE GIF RÉSEARCH}

As far as current literature is concerned, 18 papers about CSFs for the successful implementation of LSS or SS have already been published from 2002 to 2016 . These papers include surveys in which the rankirgs and imiportance factors of CSFs were calculated (see table 2). Eleven of these articles are related to s.5 and seven to LSS. In the time period from 2002 to 2009 only surveys with focus on SS were conducted. The first publications with surveys about CSFs for LSS implementation were published in the year 2010. Antony and Banueles (2002) were the first to survey critical success factors while Jesus et al. (2016) were the last researchers to publish on this subject until now. Publications of surveys about this research field peaked in the year 2012. In total, six articles were published during this year. The articles were released in different journals. Out of the 18 papers that 
have been published from 2002 until 2016, each four were published by the Journal of Quality \& Reliability Management as well as the Journal of Lean Six Sigma. All other journals only published one paper. Jiju Antony of the University of Strathclyde in Glasgow, UK, is most heavily involved in this research field. In four papers he was the lead author, one paper he published alone and six other papers he supported as co-author. It is due to this fact that most of the research was also conducted in the UK. When examining where the CSF research for the implementation of ISS or SS was predominantly conducted, it can be seen that five papers analysed the situation in the $I \mathrm{~K}$, four in Brazil, three in India, two in Malaysia and one article was written for each of the following countries: Pakistan, Italy, Netherlands, Singapore, Kenya. One publication took diirferent countries into consideration and the country of one other paper remains unkrow'n. Nine of the 18 articles focused specifically on the manufacturing industry while the service industry was the main focus in five papers. The remaining articles considered a mixt!re of different sectors. In total, 29 CSFs for the implementation of SS and LSS are ranked " "rnanagement involvement", "cultural change", "communication plan", "organizational irfrastructure and culture", "education and training", "linking SS to business strategy", "liiking SS to customer", "linking SS to human resources", "linking Six Sigma to suppliers", "understancing of SS tools and methodology", "project management skills and experience; project prioritization and selection; LSS projects tracking and review", "leadership", "organizational belief", "best practice sharing", "company financial capability", "competency of SS belts", "organizational infrastructure", "SS staff selection", "resources of LSS staff", "data based approach", "structured improvement procedure", "focus on metrics and performance goals", "vision and plan statement", "commitment of all employees", "environment of trust, ethics, integrity and respect for people", "integration of SS with financial results", "established Lean Six Sigma dashboard"). Figure 1 in the appendix shows an explanation of the most common CSFs with their respective sub-factors. 
Table 2: Empirical studies about CSFs for LSS and SS implementation

\begin{tabular}{|c|c|c|c|c|c|}
\hline Author and year & $\begin{array}{l}\text { Country of } \\
\text { research }\end{array}$ & $\begin{array}{l}\text { Quality } \\
\text { initiative }\end{array}$ & $\begin{array}{l}\text { Organization } \\
\text { size }\end{array}$ & Application sector & Journal \\
\hline $\begin{array}{l}\text { Antony and } \\
\text { Banueles (2002) }\end{array}$ & UK & SS & $\begin{array}{l}\text { Large } \\
\text { enterprise }\end{array}$ & $\begin{array}{l}\text { Services } \\
\text { Manufacturing }\end{array}$ & Measuring Business Excellence \\
\hline Antony (2004) & UK & SS & $\begin{array}{l}\text { Large } \\
\text { enterprise }\end{array}$ & Services & Managerial A \\
\hline $\begin{array}{l}\text { Antony et al. } \\
(2006)\end{array}$ & UK & SS & $\begin{array}{l}\text { Various } \\
\text { organization } \\
\text { sizes }\end{array}$ & Services & Journal of Quality \&. Reliability \\
\hline $\begin{array}{l}\text { Antony et al. } \\
(2008)\end{array}$ & UK & SS & SMES & $M a$ & $\begin{array}{l}\text { Journal of Quality \& Reliability } \\
\text { Management }\end{array}$ \\
\hline $\begin{array}{l}\text { Kumar and } \\
\text { Antony (2008) }\end{array}$ & UK & SS & SMES & Manufasturing & $\begin{array}{l}\text { Industrial Management and Data } \\
\text { Systems }\end{array}$ \\
\hline $\begin{array}{l}\text { Antony and } \\
\text { Desai, (2009) }\end{array}$ & India & & Large & Manufacturing & Management Research News \\
\hline Brun (2010) & & SS & $\begin{array}{l}\text { SMEs and } \\
\text { large } \\
\text { enterprises }\end{array}$ & Manufacturing & Journal of Production Economics \\
\hline Jaya a man ar d & Malaysia & LSS & SMES & Manufacturing & Journal of Lean Six Sigma \\
\hline $\begin{array}{l}\text { TImans et al. } \\
(2012)\end{array}$ & Dutch & LSS & SMES & Manufacturing & $\begin{array}{l}\text { Journal of the Operational } \\
\text { Research Society }\end{array}$ \\
\hline $\begin{array}{l}\text { Chakraborty and } \\
\text { Tan (2012) }\end{array}$ & Singapore & SS & Not known & Services & Business Process Management \\
\hline
\end{tabular}




\begin{tabular}{|c|c|c|c|c|c|}
\hline Desai et al. (2012) & India & SS & $\begin{array}{l}\text { SMEs and } \\
\text { Large } \\
\text { enterprises }\end{array}$ & Manufacturing & $\begin{array}{l}\text { Journal of Productivity and } \\
\text { Performance Management }\end{array}$ \\
\hline $\begin{array}{l}\text { Manville et al. } \\
\text { (2012) }\end{array}$ & Not known & LSS & $\begin{array}{l}\text { Large } \\
\text { enterprises }\end{array}$ & Services & $\begin{array}{l}\text { Journal of Quality \& Reliability } \\
\text { Management }\end{array}$ \\
\hline $\begin{array}{l}\text { Zhang et al. } \\
\text { (2012) }\end{array}$ & Pakistan & LSS & $\begin{array}{l}\text { Various } \\
\text { organization } \\
\text { sizes }\end{array}$ & Various sectors & $\begin{array}{l}\text { Interdisciplinary Journa! of } \\
\text { Contemporary Research, in } \\
\text { Business }\end{array}$ \\
\hline $\begin{array}{l}\text { Laureani and } \\
\text { Antony (2012) }\end{array}$ & $\begin{array}{l}\text { Various } \\
\text { countries }\end{array}$ & LSS & $\begin{array}{l}\text { Large } \\
\text { enterprises }\end{array}$ & $\begin{array}{l}\text { Manufacturing } \\
\text { Service }\end{array}$ & urnal of Lean Six Sigma \\
\hline $\begin{array}{l}\text { Chakraborty and } \\
\text { Chuan (2013) }\end{array}$ & Singapore & SS & $\begin{array}{l}\text { Various } \\
\text { organization }\end{array}$ & & Journal of Lean Six Sigma \\
\hline $\begin{array}{l}\text { Habidin and } \\
\text { Yusof (2013) }\end{array}$ & Malaysia & LSS & Large & Mianufacturing & Journal of Lean Six Sigma \\
\hline $\begin{array}{l}\text { Douglas et al. } \\
(2015)\end{array}$ & East Afric & & SMIES & $\begin{array}{l}\text { Service } \\
\text { Manufacturing }\end{array}$ & The TQM Journal \\
\hline Jesus et al. (2010) & Braz & SS & $\begin{array}{l}\text { Large } \\
\text { enterprises }\end{array}$ & Manufacturing & $\begin{array}{l}\text { Journal of Quality \& Reliability } \\
\text { Management }\end{array}$ \\
\hline
\end{tabular}

As far as the sizes of the organizations analysed in these surveys is concerned, it was found that these $: 8$ articles included nine surveys with focus on larger organizations while seven surveys placed their focus on SMEs. The remaining two surveys included a mixture of both. Each of the seven SMErelated surveys focused on manufacturing companies or at least included a high portion of companies from this sector (see table 3). 
Table 3: Articles about CSFs for the implementation of LSS and SS in SMEs

\begin{tabular}{|c|c|c|c|c|c|c|c|}
\hline Authors & $\begin{array}{c}\text { Douglas et al. } \\
\text { (2015) }\end{array}$ & $\begin{array}{l}\text { Brun } \\
\text { (2010) }\end{array}$ & $\begin{array}{c}\text { Kumar and } \\
\text { Antony (2008) }\end{array}$ & $\begin{array}{c}\text { Timans et al. } \\
\text { (2012) }\end{array}$ & $\begin{array}{c}\text { Desai et al. } \\
\text { (2012) }\end{array}$ & Antony et al. (2008) & $\begin{array}{l}\text { Jeyaraman } \\
\text { and Teo } \\
\text { (2010) }\end{array}$ \\
\hline Country & East Africa & Italy & UK & Netherlands & India & UK & حاح \\
\hline Number of CSFs & 11 & 12 & 13 & 12 & 12 & 11 & \\
\hline $\begin{array}{l}\text { Number of } \\
\text { respondents }\end{array}$ & 23 & 12 & 17 & 52 & 18 & & 3 \\
\hline Quality initiative & LSS & SS & SS & LSS & SS & $\overline{S S}$ & LSS \\
\hline
\end{tabular}

Brun (2010) and Desai et al. (2012) evaluated in their papers bot'n, iarge enterprises as well as SMEs.

Brun (2010) was focusing on Italian small companies while Desai tot al. (2012) was focusing on Indian small companies. Overall, four out of the six SME studies were conducted in Europe (two in UK, one in Italy and one in the Netherlands). The other tivo studies were conducted in India and East Africa. Besides Desai et al. (2012), Douglas et al. (2015) and Jeyaraman and Teo (2010) there were further researchers who conducted survevs about CSFs for LSS outside Europe. Douglas et al. (2015) published the results of a pilot study in cast African service and manufacturing organizations while Jeyaraman and Teo (2.510) explored the CSFs of LSS implementation in the multinational electronic manufacturing industy y of Malaysia. Jeyaraman and Teo (2010) are the only researchers who created a ranking of ing (SSFs without using importance factors. In total, 21 CSFs have been identified in the course of these seven SME-related surveys. Kumar and Antony (2008) considered with 13 CSFs the highesi number of CSFs. They investigated CSFs for the implementation of SS by conducting a survey wiith 17 SMEs that was carried out across the manufacturing industry in the UK. The highest number of respondents were recorded in a study with 60 UK manufacturing SMEs that was carried out by Antony et al. (2008), followed by a study conducted by Timans et al. (2012), who analysed CSFs for the LSS implementation in Dutch manufacturing SMEs, with a total of 52 respondents. 


\section{RESULTS AND DISCUSSION}

To answer the RQ1 and RQ2 table 4 was created. Table 4 presents the seven SME-related empirical studies and compares the frequency of occurrence, rank and importance factor of each CSF. In total, 21 CSFs have been identified in the course of these seven SME-related surveys. There are three CSFs that were discussed in every single article. These are "management involvement and commitmenic", "education and training" and "project prioritisation and selection". Based on the values in table 4, it can be concluded that "management involvement and commitment" is the most inipoitant CSF for the implementation of LSS or SS in SMEs. The CSFs "education and trainirig as weil as "project prioritisation and selection" are mainly ranked between the fourth and seventh place with an importance factor slightly below four in the most cases. The rext six CSFs "linking SS to the business strategy", "linking SS to customers", "linking SS to supplieis", "liriking SS to human resources", "project management skills" and "cultural change" were each found in six of the articles. Following the CSF "management involvement and commitment", the second most important CSFs for the implementation of LSS or SS in SMES are "lirking SS to the customer", "linking SS to business strategy" and "cultural change". They were ranked between the second and fourth place with an importance factor of arounc' four in most studies, followed by the CSF "project management skills" which is mainly rankeu between the fourth and seventh place with an importance factor of slightly below four. Thie CS- "inking SS to human resources" has a completely inconsistent rank throughout all the stucies and its importance factor ranges from 2.6 and 4.4. On the one hand, it was ranked at the er.d (Douglas et al. 2015; Antony et al. 2008), on the other hand, it was found in the upper ranks (Jeycraman and Teo, 2010; Kumar and Antony, 2008) and sometimes it was even ranked in the middle (Brun, 2010 and Desai et al. 2012). 
Table 4: Comparison of ranks and importance of CSFs from different SS or LSS related articles

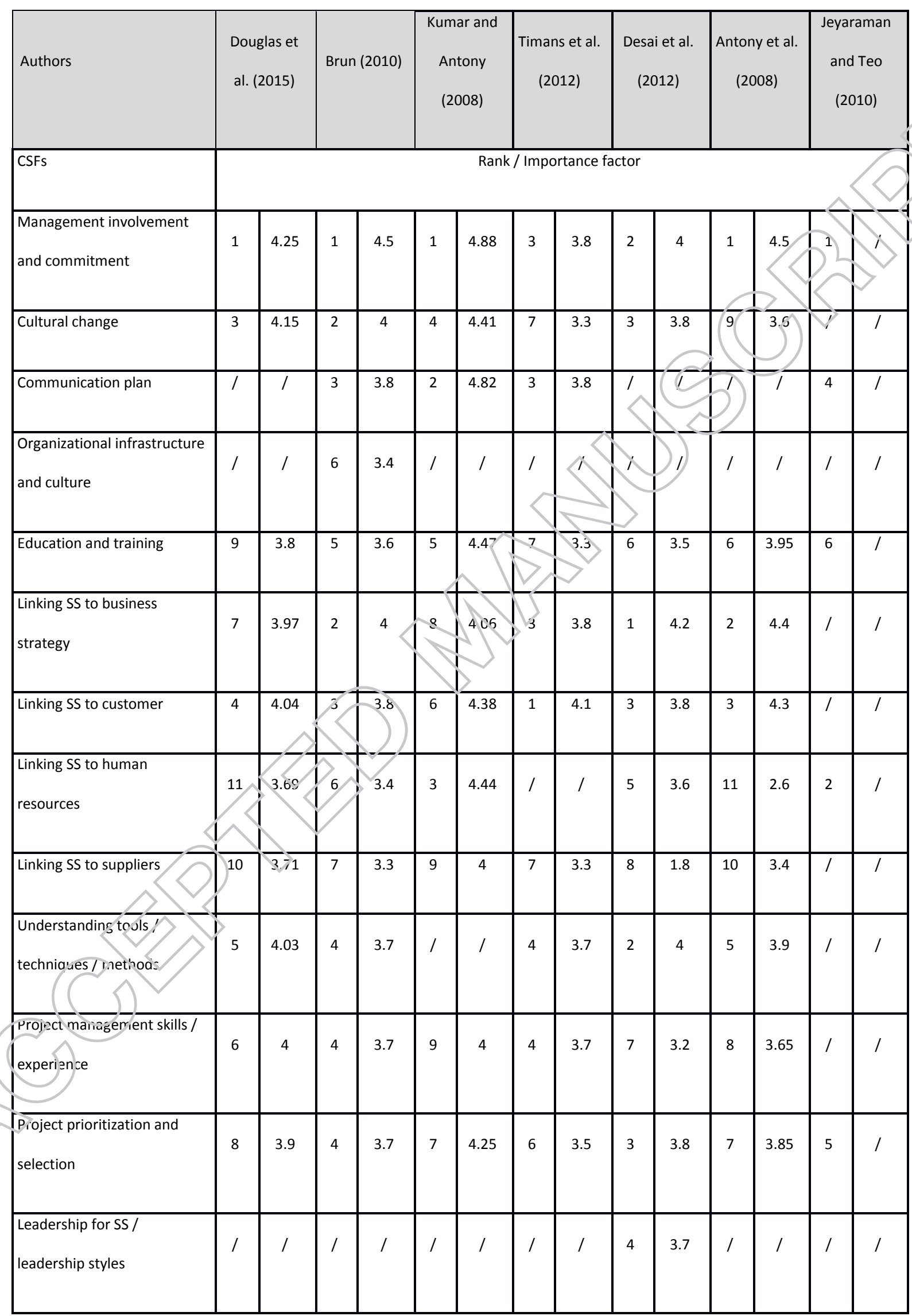




\begin{tabular}{|l|l|l|l|l|l|l|l|l|l|l|l|l|l|l|}
\hline Organizational infrastructure & 2 & 4.19 & $/$ & $/$ & 10 & 3.7 & 5 & 3.6 & 1 & 4.2 & 4 & 4 & $/$ & $/$ \\
\hline Vision and plan statement / & $/$ & $/$ & $/$ & $/$ & 11 & 3.94 & 2 & 3.9 & $/$ & $/$ & $/$ & $/$ & $/$ & $/$ \\
\hline IT and innovation & & & & & & & & & & & & & & \\
\hline
\end{tabular}

The CSF "linking SS to supplier" took throughou all studies the second last or last rank. It has never achieved an importance factor higher than fou: and in the study conducted by Desai et al. (2012) it was found to have an importance fastor of only 1.8, the lowest score recorded across all studies. According to Brun (2010), a company should gain a comprehensive understanding of the methodology first before initiating any attempts of transferring it to its any suppliers. Additionally, it needs to be considered that the availability of financial resources could limit the scope of the application of LSS or SS in SMEs. Against this background, most companies decide to focus primarily on some aspecis of the methodology and usually pay little attention to "linking SS to supplier". "Oiganizational infrastructure" and "understanding of SS tools and methodology" are the next two CSFs that were evaluated in five articles each. The importance factor of both CSFs was measured at Ground four in most cases. As far as the ranking of these two CSFs is concerned "SS tools and methodology understanding" was found to be between the fourth and fifth place while the CSF "organizational infrastructure" is ranked very inconsistently throughout the various papers. The CSF "communication plan" is ranked in four articles and the CSF "vision and plan statement" in two 
articles. The CSF "communication plan" is rated twice on the third rank and once on the second rank with an importance factor of even as high as 4.82 . It can be concluded that it belongs like the CSFs "linking SS to business strategy", "linking SS to customers" and "cultural change" to the second most important CSFs for the implementation of LSS in SMEs. The CSF "vision and plan statement" was ranked twice with a completely different score whereby the importance factor of 3.9 was idenical. There are seven additional CSFs ("organizational belief and culture", "company financial capability" "lessons learned", "master black belt and black belt competencies", "established Ss dashboard", "leadership for SS" and "IT and Innovation") that have only been considered in one su vey until now. Considering the rankings of these studies, it can be concluded that the priority of all the CSFs may not be so different from each other. It must be noted, however, that the ranks and importance factors reported in one or two of the studies constitute an exception as their results vary greatly from all other studies.

To answer the RQ3 and to determine whether or hot ranks and importance factors of the CSFs for SMEs are identical or different for larger enterprises, a comparison between these both organization sizes will be conducted. Therefore, six additional research papers from Europe, India and Brazil concerning CSFs for the impiernentation of SS and LSS in large manufacturing enterprises were taken into consideration. Compared to the previous investigative approach, an analysis using the ranking is more difficult in this case as the number of CSFs evaluated in the studies related to larger enterprises is visyally bigher. Examples for this are Laureani and Antony (2012) as well as Jesus et al. (2016 who doth considered 19 CSFs in their studies. Due to this fact only a comparison between the importance factors of the individual CSFs was carried out. In order to make this comparison an average importance factor of each CSF for SMEs and larger enterprises was calculated based on data taken from the analysed articles. Subsequently, the newly calculated average importance factors were used to create a new ranking for SMEs as well as larger enterprises. The paper written by Jeyaraman and Teo (2010) was excluded from this analysis as they only created a ranking of CSFs without importance factors. Overall, 14 congruent critical success factors were considered relevant 
for large enterprises as well as for SMEs. The results of this comparison analysis are shown in table 5. Based on the newly calculated average importance factors it can be concluded that there are no significant variations between the importance of CSFs for implementing LSS in SMEs and larger enterprises. The CSF "management involvement and commitment" is the most important CSF, irrespective from the organization size. Despite the many differences between SMEs and larger enterprises, LSS requires the same kind of management support and commitment. The folioving three CSFs "communication plan", "linking SS to the business strategy" and "linking SS no sustomers" are to be found between the ranks two and four in SMEs as well as in larger enterprises. The CSF "organizational infrastructure" is ranked fifth and the CSF "linking SS to suppiiers" ranks at the end for both organization sizes. Moreover, the other CSFs "understanding SS tools", "education and training", "project prioritization and selection", "linking SS to humian resources" nearly rank the same in both organization sizes. They are very close together and only differ from each other by one or two ranks. The remaining three CSFs "c iltural change", "leadership styles" and "project management skills" differ from each other by t'ree ranks.

Table 5: Comparative Arailysis or CSF sor the implementation of LSS in SMEs and large enterprises

\begin{tabular}{|c|c|c|c|}
\hline Organization size & Large organizations & & SME \\
\hline & $\begin{array}{l}1 \text { = Laureani and Antony (2012), } 2 \text { = Brun } \\
\text { (2010), } 3 \text { = Antony and Banueles (2002), } \\
=\text { Desai et al. (2012), } 5 \text { = Jesus et al. (2016); } \\
\text { Antony and Desai (2009) }\end{array}$ & $\begin{array}{c}4 \\
6=\end{array}$ & $\begin{array}{l}1 \text { =Douglas et al. (2015); } 2 \text { = Brun (2010); } \\
=\text { Kumar and Antony (2008); } 4 \text { = Timans et al. } \\
\text { (2011); } 5 \text { = Desai et al. (2012); } 6 \text { = Antony et al. } \\
\text { (2008) }\end{array}$ \\
\hline Ccuntry & $\begin{array}{l}\text { 1=Different countries;; } 2=\text { Italy; } 3=\text { UK; } \\
=\text { India; } 5 \text { = Brazil; } 6=\text { =India }\end{array}$ & & $\begin{array}{l}1 \text { = East Aftrica; } 2 \text { = Italy; } 3 \text { = UK; } \\
\text { Netherlands; } 5 \text { = India; } 6 \text { = UK }\end{array}$ \\
\hline Number of CSFs & $1=19 ; 2=12 ; 3=11 ; 4=12 ; 5=19 ; 6=11$ & & $1=11 ; 2=12 ; 3=13 ; 4=12 ; 5=12 ; 6=11$ \\
\hline Number of respondents & $1=102 ; 2=12 ; 3=16 ; 4=61 ; 5=29 ; 6=43$ & & $1=23 ; 2=12 ; 3=17 ; 4=52 ; 5=18 ; 6=60$ \\
\hline
\end{tabular}




\begin{tabular}{|c|c|c|c|c|c|c|}
\hline CSFs & Rank & Importance & Frequency & Rank & Importance & Frequency \\
\hline $\begin{array}{l}\text { Management involvement and } \\
\text { commitment }\end{array}$ & 1 & 4.43 & 7 & 1 & 4.32 & 6 \\
\hline Cultural change & 9 & 3.76 & 5 & 5 & 3.88 & 6 \\
\hline Communication plan & 4 & 4.07 & 4 & 2 & 4.14 & \\
\hline $\begin{array}{l}\text { Organizational infrastructure and } \\
\text { culture }\end{array}$ & 10 & 3.7 & 3 & 12 & 3.4 & \\
\hline Education and training & 11 & 3.68 & 7 & 8 & $\overline{3} . \overline{77}$ & 6 \\
\hline Linking SS to business strategy & 2 & 4.24 & 7 & & $4 . \overline{17}$ & 6 \\
\hline Linking SS to customer & 3 & 4.1 & 7 & 3 & 4.07 & 6 \\
\hline Linking SS to human resources & 13 & 3.39 & & 13) & 3.55 & 5 \\
\hline Linking Six Sigma to suppliers & 14 & 3.38 & 1 & 13 & 3.25 & 6 \\
\hline Understanding tools and techniques & 8 & $\overline{3} . \overline{9}$ & 7 & 6 & 3.87 & 5 \\
\hline Project management skills & 12 & 3.61 & 6 & 9 & 3.71 & 6 \\
\hline Project prioritization and selection & & 3.96 & 7 & 7 & 3.83 & 6 \\
\hline Leadership for SS & & 3.95 & 3 & 10 & 3.7 & 1 \\
\hline Organizational infrastrict & 5 & 4 & 4 & 4 & 3.94 & 5 \\
\hline
\end{tabular}

To answer the RQ/ and further explore the differences between the identified CSFs for SMEs and large corporations, five groups were created to emphasize the priority of CSFs more profound: top priority; high priority; mid-priority; low priority; lower priority (Table 6). The values of 20, 40, 60 and 80 percentiles for both groups of the CSFs were calculated and used as cut-out values for the distribution of the CSFs. The approach of grouping CSFs based on the percentile values allows a comparability of the identified CSFs groups (Heeringa, West and Berglund, 2010). The developed classification of priority groups provides further interesting insights in the role of different CSFs for 
the successful implementation of LSS and SS in manufacturing SMEs and large corporations. According to the percentile ranking of the CSFs, the group of top priority CSFs for both organization sizes include the CSFs "management involvement and commitment" accompanied by the CSF "linking SS to business strategy". Interestingly, for SMEs top priority CSFs additionally include the CSFs "communication plan" and "linking SS to customers". The difference in this group demonstrate that for SMEs to implement LSS and SS it is necessary to focus on communication within interrial and external environment. Possible explanation of this finding could lie in the relative closeness of customers to small businesses as compared to large corporations, which allo'vs for almost immediate feedback from customers to the changing operations. For soin sinEs and large corporations, the CSF "organizational infrastructure" is a high priority CSF. However, for SMEs this group additionally includes the CSF "cultural change" while for large corporations the CSFs "communication plan" and "linking SS to customers" it should be noted that for large corporations, the CSF "cultural change" is rather a low priorit, CSE. This is a surprising finding taking into account numerous research claiming the need of a cu'tural change to support SS implementation (Barney, 1986; Bortolotti, Boscari, and Danese, 2015; McLean, Antony and Dahlgaard, 2017).

Table 6: Priority grouping of CSFs based on percentile ranking

\begin{tabular}{|c|c|c|c|c|c|c|c|c|c|}
\hline \multirow[t]{2}{*}{ Group } & \multirow[t]{2}{*}{ Perier.iles } & \multicolumn{4}{|c|}{ Large enterprises } & \multicolumn{4}{|l|}{ SMES } \\
\hline & & Range & CSF & $\begin{array}{l}\text { Impor- } \\
\text { tance }\end{array}$ & $\begin{array}{l}\text { Percentile } \\
\text { of CSF }\end{array}$ & Range & CSF & $\begin{array}{l}\text { Impor- } \\
\text { tance }\end{array}$ & $\begin{array}{l}\text { Percentile } \\
\text { of CSF }\end{array}$ \\
\hline $\begin{array}{l}\text { Top } \\
\text { CSFiority } \\
\text { CSFs }\end{array}$ & $80-100$ & $\begin{array}{l}4.10- \\
4.43\end{array}$ & $\begin{array}{l}\text { Management } \\
\text { involvement } \\
\text { and } \\
\text { commitment }\end{array}$ & 4.43 & 0.933 & $\begin{array}{l}4.07- \\
4.32\end{array}$ & $\begin{array}{l}\text { Management } \\
\text { involvement } \\
\text { and } \\
\text { commitment }\end{array}$ & 4.32 & 0.933 \\
\hline & & & & & & & Communicati & 4.14 & 0.866 \\
\hline
\end{tabular}




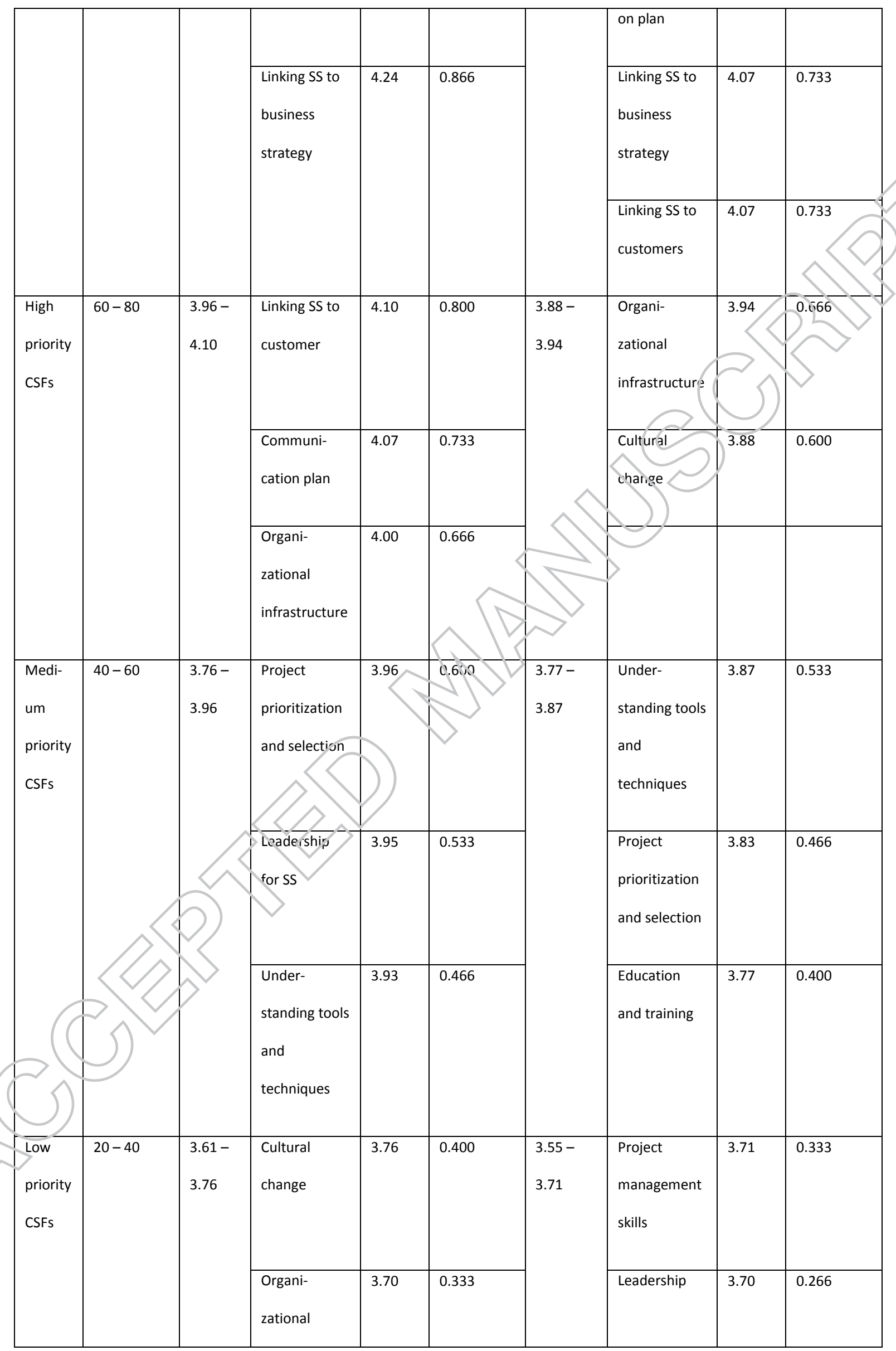




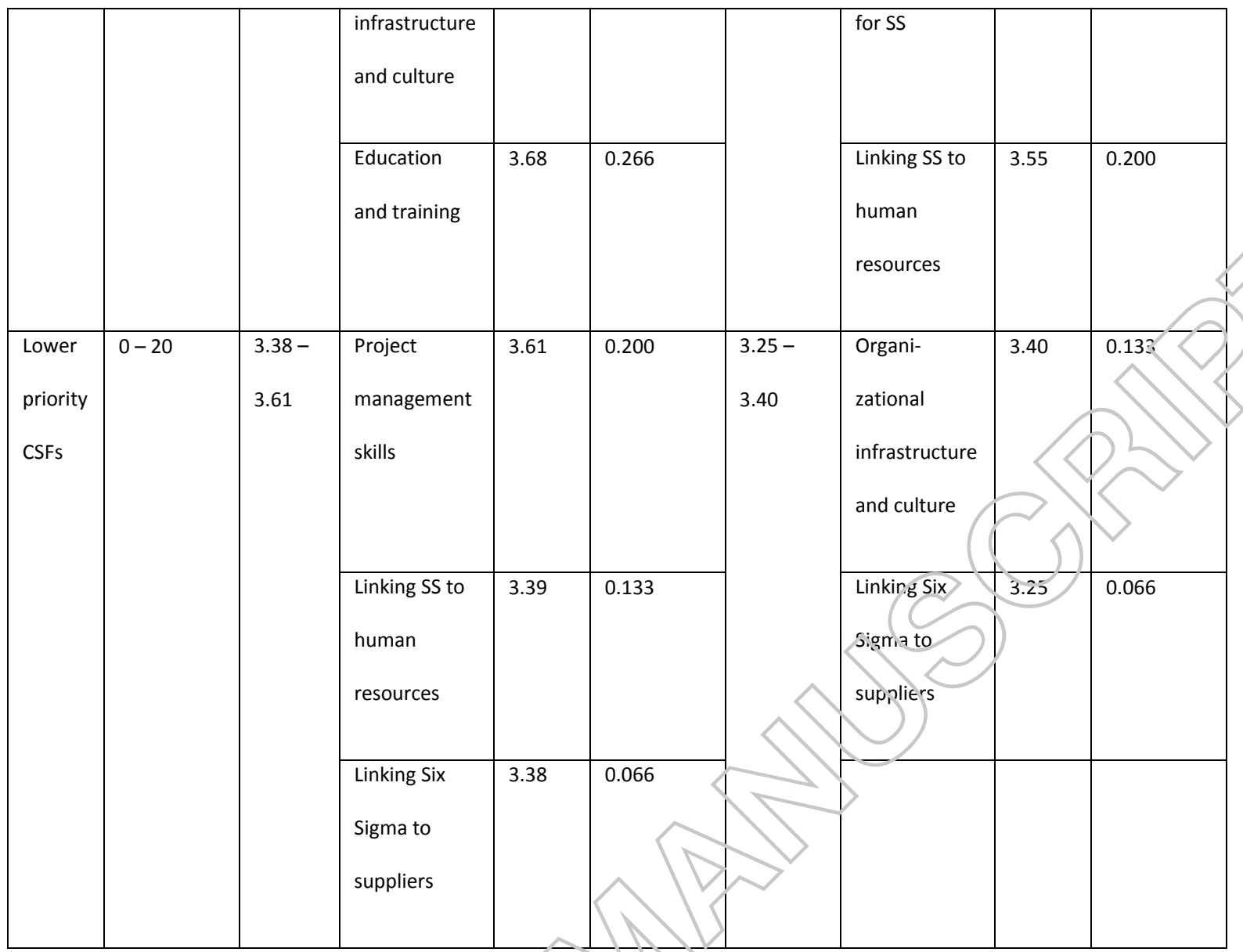

The group of medium priority CSFs for both organizatich sizes include the CSFs "project prioritization and selection" and "understanding toois and tecíniques". For SMEs it additionally includes the CSF "education and training" while for iarge corporation this CSF falls into the group of the low priority CSFs; thus, it can be consiuded that kniowledge of the LSS tools and their application has a major role for the successful/LSS imp'ernentation. For large organizations this group also includes the CSF "leadership for SS". Interestingly, that for SMEs this CSF is one of the low priority CSFs. Arguably, large grganizations require a more sophisticated system of the leadership for SS due to their size and complicated communication within multiple dispersed departments, as compared to SMEs. Based on the conducted priority grouping of the CSFs, it can be further concluded that for both SMEs and large organizations the framework for successful LSS implementation should include a set of CSFs. So far, only one useful framework has been developed by Kumar et al. (2011) and it was later revised by Timans et al. (2016). The results of this study can be used as an input for the optimization of this LSS implementation framework. Both types of the organization require management commitment and 
involvement as well as alignment of SS to the business strategy to drive the LSS initiative forward. However, SMEs should put a stronger focus on the alignment of SS to customers, cultural change, providing employees with appropriate training and developing communication inside and outside the organization. Large organizations, in contrary to SMEs, should rather prioritize to develop a leadership for SS initiatives. Further research is needed to examine whether the nature of the relationship between identified CSF is combinatorial or additive (Jinhui Wu, Melnyk arid Swink, 2012).

\section{CONCLUSION}

The objective of this paper was to review CSFs for the successfu! implernentation of LSS and SS in manufacturing SMEs. The novelty of this paper lies in the coriduct of a comparative study on the importance and priority of CSFs between only SME-related articias as well as between SME and large enterprise related articles. Further, a classification of the :dentified CSFs was developed according to the priority based on a percentile ranking. For the comparative analysis within the SME field, seven articles from Europe, Asia and Africa were considered. Overall, 21 CSFs occur throughout all of these articles. More than half of the ESFs are rated in at least five articles ("management commitment", "cultural change", "education and training", "linking SS to the business strategy", " linking SS to the customers", "linking SS to the human resources", "linking SS to the suppliers", "understanding of SS tools", "project management skills", "project prioritization and skills", "organizational infrasiructure"). It can be concluded that the ranks and the importance factors of the individual CSFs are rated aimiost similar in the different articles. One or two articles constitute an exception as their results are completely different in comparison to the results of the majority of the studies. According to the findings of the assessment "top management commitment" is the most essential CSF for the implementation of LSS or SS in manufacturing SMEs. Here, the authors of all seven articles agree unanimously. It is followed by the CSFs "linking SS to the customer", "linking SS to the business strategy", "communication plan" and "organizational infrastructure". It was also found that the CSF 
"linking SS to supplier" is frequently found in the end of the rankings and, therefore, can be considered as the least relevant CSF.

For the comparison analysis regarding the importance factors of CSFs between SMEs and large enterprises, six additional papers from Europe, India and Brazil with focus on CSFs for implementins LSS and SS in large manufacturing enterprises were taken into consideration. It must be pointed out that the relevance of the CSFs for the LSS and SS implementation is similar for both orgarization. sizes. To outline differences and similarities in the priority of CSFs for SMEs and large corporation more profound, the identified CSFs were grouped according to a percentile distribution into five groups: top priority; high priority; medium priority; low priority; lover prisrity. To succeed in the implementation of LSS and SS, both sizes of organizations require management commitment and involvement coupled with alignment of SS to the busiress sirategy. For SMEs, in addition, it is necessary to develop a good communication plan and link ss to customers. Current research literature suggests that there is a need to implement a set of CSFs to ensure successfulness of LSS and SS implementation.

Moreover, many CSFs were evailuated only n one survey so far. Five out of ten CSFs ("organizational belief and culture", "compariy finar, ciăl capability", "lessons learned", "master black belt and black belt competencies", "estailished LSS dashboard") from the Jeyaraman and Teo (2010) survey were, for example, not considered in any other SME related papers until now. These CSFs were also not evaluated based on the respondents perceived importance of a five-point Likert scale. Furthermore, the CSFS "IT and innovation" and "leadership for SS" were only evaluated in one paper so far. Within the scope of further research activities it is recommended to use these CSFs for the assessment of a wider range of CSFs in order to get a better understanding of the requirements for a successful implementation of LSS and SS in manufacturing SMEs. This can only be achieved by undertaking more and more practical studies, empirical studies and expert interviews in different regions of the world. If CSFs are not closely observed, the implementation of such strategies may proof challenging 
and it will be difficult to achieve a high degree of competitiveness for SMEs. Research regarding frameworks for the LSS or SS implementation in SMEs is still at the beginning. The results of the present study can be used as an input to improve the existing frameworks as well as guidance for the development of guidelines for manufacturing SMEs on the implementation of LSS and SS.

\section{REFERENCES}

1. Albliwi, S. A., Antony, J. and Lim, S. A. H. (2015) 'A systematic review of Lean Six Sigma for the manufacturing industry', Business Process Management Journal, Vol. 21, No. 3, po. 665- 691.

2. Antony, J. (2004) 'Six Sigma in the UK service organizations: results from a pilot survey', Managerial Auditing Journal, Vol. 19, No. 8, pp. 1006-1013

3. Antony, J. and Desai, D.A. (2009), 'Assessing the status of Six Sigma implementation in the Indian industry', Management Research News, Vol. 32, iNo. 5, pp. 413-423.

4. Antony, J., Antony, F.J., Kumar, M. and Cho, B. R. (2007) 'Six Sigma in service organizations: benefits, challenges and difficlitities, common myths, empirical observations and success factors', International Journal of Quality \& Reliability Management, Vol. 24, No. 3, pp. 294311.

5. Antony, and Banuelas, R. (2002) 'Key ingredients for the effective implementation of Six Sigma program, Measuring Business Excellence, Vol. 6, No. 4, pp. 20-27.

6. Ants,ny, J., Kumar, M. and Madu, C.N. (2005) 'Six Sigma in small and medium-sized UK manufacturing enterprises', International Journal of Quality \& Reliability Management, Vol. 22, No. 8 , pp. $860-74$.

7. Antony, J., Kumar, M. and Labib, A. (2008) 'Gearing Six Sigma into UK Manufacturing SMEs: Results from a Pilot Study', The Journal of the Operational Research Society, Vol. 59, No. 4, pp. $482-493$. 
8. Arnheiter, E. D. and Maleyeff, J. (2005) 'The integration of lean management and Six Sigma', The TQM Magazine, Vol. 17, No. 1, pp. 5-18.

9. Barney, J. B. (1986) 'Organizational culture: can it be a source of sustained competitive advantage?', Academy of Management Review, Vol. 11, No. 3, pp. 656-65.

10. Brun, A. (2010) 'Critical success factors of Six Sigma implementations in Italian companies', International Journal of Production Economics, Vol. 13, No. 1, pp. 158-164.

11. Bortolotti, T., Boscari, S. and Danese, P. (2015) 'Successful lean implemen ation: Organizational culture and soft lean practices', International Journcil of Production Economics, Vol. 160, pp. 182-201.

12. Chakraborty, A. and Tan, K.C. (2012) 'Case study analysis of Six Sigma implementation in service organizations', Business Process Management, vol. 18, No. 6, pp. 992-1019.

13. Chakraborty, A. and Chuan, T.K. (2013) An ernpirical analysis on Six Sigma implementation in service organizations', International Journùl of Lean Six Sigma, Vol. 4, No. 2, pp. 141-170.

14. Coronado, R. B. and A.nton:y, J. (2052) 'Critical success factors for the successful implementation, of Six Sigma projects in organizations', The TQM Magazine, Vol. 14, No. 2, pp. $92-99$.

15. Desai, D. A, A.ntony, J. and Patel, M. B. (2012) 'An assessment of the critical success factors for Six Sigma implementation in Indian industries', International Journal of Productivity and Performance Management, Vol. 61, No. 4, pp. 426-444.

16. Deshmukh, S. V. and Chavan, A. (2012) 'Six Sigma and SMEs: a critical review of literature', International Journal of Lean Six Sigma, Vol. 3, No. 2, pp. 157-167.

17. Douglas, A., Douglas, J. and Ochieng, J. (2015) 'Lean Six Sigma implementation in East Africa: findings from a pilot study', The TQM Journal, Vol. 27, No. 6, pp. $772-780$. 
18. European Commission (2005) 'The new SME definition: user guide and model declaration', Luxembourg: European Commission.

19. Gagliardi-Main, D., Muller, P., Glossop, E., Caliandro, C., Fritsch, M., Brtkova, G., and Ramlogan, R. (2013) `ANNUAL REPORT ON EUROPEAN SMEs 2012/2013: A recovery on the Horizon?', SME Performance Review.

20. Griffin, R. K. (1995) 'A categorization scheme for critical success factors of lodging yie.d management systems', International Journal of Hospitality Management, Yol 14, No. 3-4, pp. 325-338.

21. Habidin, N.F. and Yusof, S.M. (2013), 'Critical success facters of Lean Six Sigma for the Malaysian automotive industry', International Journa! of Lean Six Sigma, Vol. 4, No. 1, pp. 6082.

22. Husband, S. and Mandal, P. (1999) 'A concepiua! Irodel for quality integrated management in small and medium size enterprises', International Journal of Quality and Reliability Management, Vol. 16, No. 7, pp. 6.99-713.

23. Heeringa, S. G., West, B. T and Berglund, P. a. (2010) Applied Survey Data Analysis. Boca Raton, FL: C.RC Press.

24. Jayaramar., K. and Teo, L.K. (2010) 'A conceptual framework for critical success factors of Lean Six Sigma', International Journal of Lean Six Sigma, Vol. 1, No. 3, pp. 191-215.

25. Jenster, P. V. (1987) 'Using critical success factors in planning', Long Range Planning, Vol. 20, No. 4, pp. 102-109.

26. Jesus, A., Antony, J., Lepikson, H. and Peixoto, A. (2016) 'Six Sigma critical success factors in Brazilian industry', International Journal of Quality \& Reliability Management, Vol. 33, No. 6, pp. $702-723$. 
27. Jie, J. C. R., Kamaruddin, S. and Azid, I. A. (2014) 'Implementing the Lean six sigma framework in a small medium enterprise (SME) - a case study in a printing company', International conference on industrial engineering and operations management Bali, January, pp. 7-9.

28. Jinhui Wu, S., Melnyk, S. A. an Swink, M. (2012) 'An empirical investigation of the combinatorial nature of operational practices and operational capabilities' Internationd Journal of Operations \& Production Management, Vol. 32, No. 2, pp. 121-155.

29. Kifayah, A. and Douglas, D. (2008) 'A Review of Six Sigma Implementation Frameworís and Related Literature', IANG: International Conference on Industrial Engineerina.

30. Kumar, M., Antony, J., Singh, R. K., Tiwari, M. K., and Perry, D. (2006) implementing the Lean Sigma framework in an Indian SME: a case study', Production Piúrining and Control, Vol. 17, No. 4, pp. 407-423.

31. Kumar, M. and Antony, J. (2009) 'Investigating the quality management practices in Six Sigma against Non-Six Sigma UK manufacturing SiMEs: key findings from multiple case studies', Journal of Engineering Manufacture, IMECH E Part B, Vol. 223, No. 7, pp. 925-934.

32. Kumar M. and Antoriy' (2058) 'Comparing the quality management practices in UK SMEs', Industrial Mianugement and Data Systems, Vol. 108, No. 9, pp. 1153-1166.

33. Kuniai, M1, Antony, J. and Tiwari, M. K. (2011) 'Six Sigma implementation framework for SIVEs-a roadmap to manage and sustain the change', International Journal of Production Research, Vol. 49, No. 18, pp. 5449-5467.

34. Laureani, A. and Antony, J. (2012) 'Critical success factors for the effective implementation of Lean Sigma', International Journal of Lean Six Sigma, Vol. 3, No. 4, pp. 274 - 283 
35. Manville, G., Greatbanks, R., Krishnasamy, R. and Parker, D.W. (2012) 'Critical success factors for Lean Six Sigma programmes: a view from middle management', International Journal of Quality \& Reliability Management, Vol. 29 No. 1, pp. 7-20.

36. McLean, R. S., Antony, J. and Dahlgaard, J. J. (2017) 'Failure of Continuous Improvement initiatives in manufacturing environments: a systematic review of the evidence' ,Total Qualit:) Management \& Business Excellence, Vol. 28, No. 3-4, pp. 219-237.

37. Okoli, C. and Schabram, K. (2010) 'A guide to conducting a systematic literaiure revie'w of information systems research', Sprouts: Working Papers on Information Sy'stems, Vol. 10, No. 26, pp. 1-51.

38. Pepper, M. P. J. and Spedding, T. A. (2010) 'The evolution of Iean Six Sigma', International Journal of Quality \& Reliability Management, Vol. 27. No. 2, pp. 138-155.

39. Pyzdek, T. (2003) The Six Sigma handbook. A comp!ete Guide for Green Belts, Black Belts, and Managers at All Levels, New York, USA: McGraw-Hill.

40. Rockart, J. F. (1978) 'Chiet executives define their own data needs', Harvard Business Review, Vol 57, No. 2, pp. 238-241

41. Rowlands, ㄴ. (2004) 'IInplementation issues of Six Sigma in an SME', First International Confererict on Six Sigma, Vol. 16.

42. Timans, W., Antony, J., Ahaus, K. and van Solingen, R. (2012) 'Implementation of Lean Six Sigma in small- and medium-sized manufacturing enterprises in the Netherlands', Journal of the Operational Research Society, Vol. 63, No. 3, pp. 339-353.

43. Timans, W., Ahaus, K., van Solingen, R., Kumar, M. and Antony, J. (2016) Implementation of continuous improvement based on Lean Six Sigma in small- and medium-sized enterprises', Total Quality Management and Business Excellence, Vol. 27, No. 3-4, pp. 309-324. 
44. Zhang, Q., Irfan, M., Khattak, M.A.O., Abbas, J., Zhu, X. and Shah, M.S. (2012) 'Critical success factors for successful Lean Six Sigma implementation in Pakistan', Interdisciplinary Journal of Contemporary Research in Business, Vol. 4, No. 1, pp. 117-124.

Appendix

The most frequent CSFs for LSS implementation in SMEs have been identified through a thorough. review of the literature from the publications of Douglas et al. (2015), Brun (2015) Kumar and Antony (2008), Timans et al. (2011), Desai et al. (2012), Antony et al. (2008). Figure 1 includes a description of critical success factors with their sub-elements.

1. Management involvement and participation:

a. Understanding of the Six Sigma methodology by the top mariagement

b. Top management participation in Lean Six Sigma projects

c. Project verification by the top management

d. Provision of appropriate budget and resources for a project

2. Organisational infrastructura:

a. Havins appropriate budget and resources for the execution of LSS projects

b. Creation of cross-functional teams within the organisation

c. Hâ. Ing employee participation in LSS implementation

d. Facilitate leadership behaviour

3. Cultural change:

a. Showing differences between LSS and other quality improvement initiatives 

b. Establishing the need for LSS in terms of benefits to the employees at all levels
c. Communicating values and beliefs involved in LSS deployment
d. Communication on the "why" and "how" of LSS
e. Demonstrating lost opportunities if LSS is not implemented

\section{Training and education:}

a. Leaders identify the key roles of the people directly involved in applying Six Sigma;

b. Leaders apply a belt (Green Belts, Black Belts, Master Black Belts, Chainnionsis system throughout the organisation

c. Leaders must be involved in selecting the most talented people for training and project execution.

\section{Linking LSS to customers:}

a. Identification of customer (internal/external) needs

b. Ensure that LSS projects begin with the determination of the customer (internal/external) requirements

c. Impiernentation or projects with high impact on customer satisfaction

a Setiins project goals based on reducing the gap between the company's expected and the company's actual performance, especially in terms of customer satisfaction

e. Understanding the market and evaluating it periodically

f. Getting involved in developing processes to resolve external customer Complaints 


\section{Linking LSS to business strategy:}

a. Financial appraisal of Six Sigma projects

b. Target LSS projects on improvements that have a direct impact on the financial and operational goals of the company

\section{Linking LSS to employees:}

a. To make LSS training mandatory for promotion consideration

b. To provide rewards and recognition to employees based on successfuil implementation of Six Sigma projects

c. To use Six Sigma accomplishments as the key measure tor marıagement performance and compensation

\section{Linking LSS to suppliers:}

a. To involve suppliers in LSS projects

b. To have suppliers who have inplemented LSS

c. Establishing effective ty/o-way communication with suppliers

d. Having cietailed supplier's performance information

\section{9. indeistariding of LSS methodology:}

a. To understand fully ALL steps of the DMAIC/DFSS/DMEDI/IDOV methodology

b. To adapt LSS methodology to your organisation

c. To use simple tools and techniques during LSS implementation

10. Project management skills: 

a. To develop project management skills
b. To establish a project score card

\section{Project prioritisation and selection:}

a. Project selection based on financial returns

b. Project prioritisation based on customer requirements

c. Project prioritisation based on critical business processes

e. Project selection focused on poorly performing areas of the company

f. Project selection based on cost of poor quality

\section{Leadership for LSS:}

a. Leadership assuring linkage of LSS to corporiate business strategy

b. Leadership actions are supported at all ievels of decision making through the use of facts and data

c. Leaders participation in 1.35 projects

d. Leaders to be involved in project review/verification

e. Leadership to reflect on best and worst management practices in the implementation of projects

f. Leadership encouraging employee participation in LSS implementation

g. Leaders to communicate values and beliefs involved in LSS deployment

h. Leaders should make sure LSS projects should begin with the determination of internal/external customer requirements 


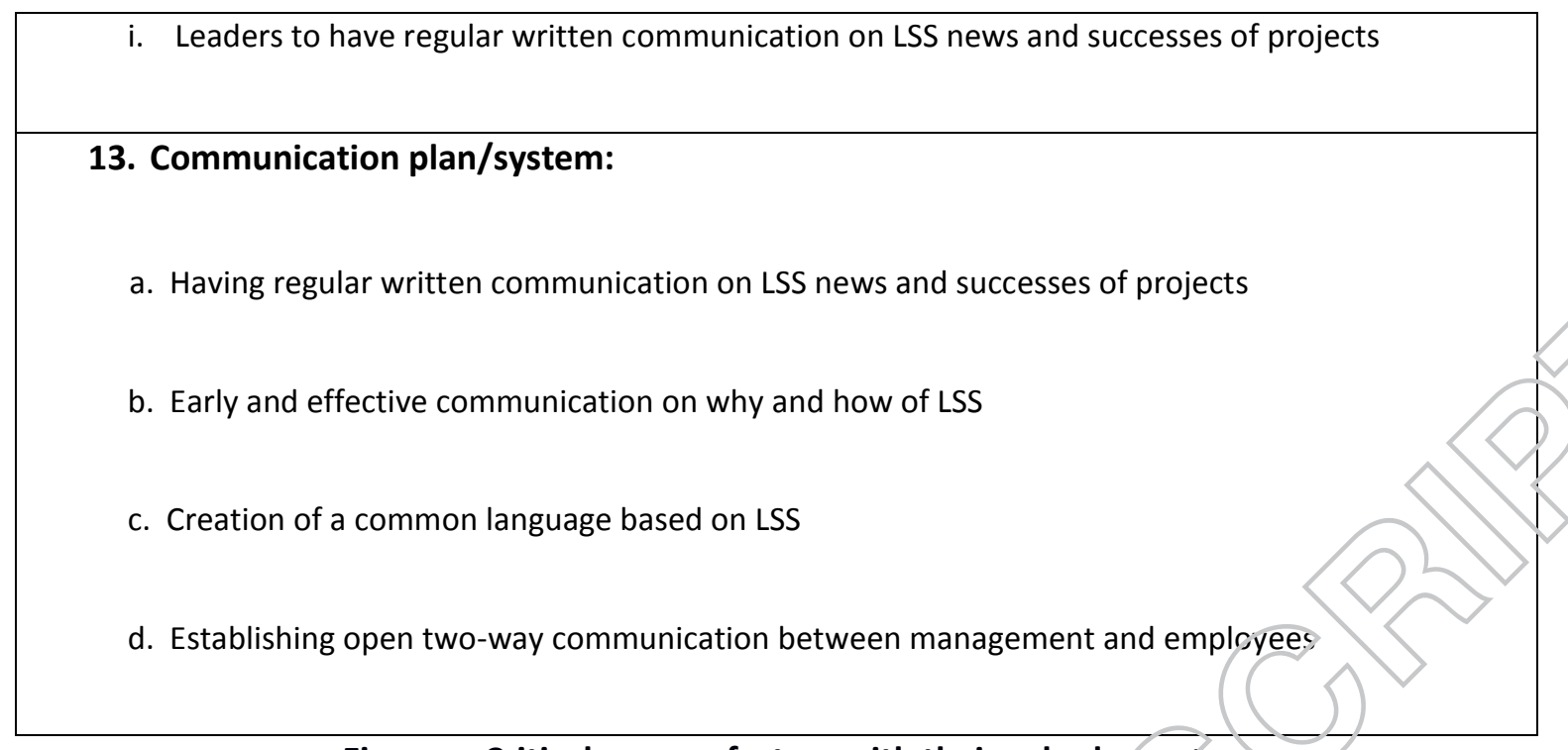

Figure 1: Critical success factors with their sub-elernerics

\section{ACKNOWLEDGMENTS}

The authors are thankful to the Internal Grant Agency of Tornas Bata University in Zlín, No.

IGA/FaME/2018/005 as well as Visegrad Fund (grant No. 5.1700045) for financial support to carry out research.

\section{ABBREVIATIONS}

Critical Success Factors

CSFs

Six Sigma

SS

Lean Six Signia

LSS

Smail and miedium-sized enterprise

SME

\section{Conitact information}

Roland Stankalla, M.Sc., M.Sc

Oksana Koval, M.Sc.

Prof. Dr.-Ing. Felicita Chromjakova 
Tomas Bata University

Faculty of Management and Economics

Department of Industrial Engineering and Information Systems

Mostni 5139, 76001 Zlin, Czech Republic

Email: roland.stankalla@yahoo.com 